discussants. In other words, $39.1 \%$ of the female chairs in the convention's Program Committee organized panels were found in the sections organized by women as were $34.5 \%$ of the female papergivers and $35.3 \%$ of the female discussants. (Womenchaired panels had $40.5 \%$ female papergivers and $43.6 \%$ of the discussants. These constituted $23.3 \%$ of the convention's panels yet had $41.4 \%$ of the women giving papers and $48.2 \%$ of the women serving as discussants!)

The sections with the strongest female representation were those on Law, Courts and Judicial Process; Policy Studies; Representation and Electoral Systems; Women and Politics Research; Comparative Politics-Second World; The Bill of Rights; Liberte, Equalite, Fraternite: The French Revolution at 200; and the Committee on the Status of Women.

The sections with the weakest female representation in 1989 were those on Conflict Processes, Federalism and Intergovernmental Relations, Legislative Studies, Science and Technology Studies, Comparative Politics-First World, The Civil Rights Act of 1964, Thomas Hobbes: 1588-1988, and Computer Uses.

Among the lopsidedly male panels were those on Modeling Interstate Conflict; Rational Choice and Collective Political Action; Defense Spending, Arms Control and Interstate Politics; Senate Elections: Reports from the 1988 NES State Study; Roundtable on Interest Groups and Public Policy in Pluralist Industrial Democracies; The Presidential-Congressional Nexus: New Firsts on Recruitment Issues; Public Opinion and U.S. Foreign Policy; Political Organization in Western Democracies; Rational Choice Approaches; Measuring the Effects of the Voting Rights Act; The Bill of Rights: Individual, Institutional, Minority, Majority Perspectives; and Information Intermediaries in Election Campaigns: Cross-National Comparisons.

Panels overwhelmingly female included Roundtable on Postmodernism, Critiques of Cultural Imperialism and the Identity Crisis for Feminism, Women and Bureaucracy, Women and the Law, The Impact of Women in U.S. State Legislatures, Roundtable on Feminists' Conception of Peace, and Organizing Academically: The Experi- ence of the Women's Caucus for Political Science.

The evening plenary sessions were, as usual, mostly occasions for males to be in the spotlight. (However, two of the five "Trivialists" in 1989 were women.)

\section{Women's Caucus for Political Science Celebrates 20th Anniversary}

$\mathbf{W}$ omen's Caucus for Political Science founded in 1969 celebrated its 20th Anniversary at the Atlanta Annual Meeting. To mark their anniversary, Caucus members recognized 28 "mentors." What is a mentor? A composite "portrait of a mentor" is gleaned from the many nomination letters received by the Caucus:

He encouraged me to go to graduate school in political science when most other people discouraged me, and encouraged me to do work on women and politics. She offered me a research assistantship and taught me how to do research. She played a pivotal role in the creation of Women and Politics as a major concentration within our graduate political science program. She never gave up on me, even when I was "buried" "raising two small children. He must have directed the dissertations of more women in political science than any other person in the history of the discipline. To this day she devotes time and energy helping me negotiate publication strategies and various career decisions. I am now a full professor and was selected 1988 Teacher of the Year by my College-that is my testimonial to her.

The mentors honored at the Atlanta meeting included:

Carolyn Ban, SUNY

Bernard E. Brown, CUNY Graduate Center

Philip Burgess, U.S. West Telephone Co.

Susan ]. Carroll, Rutgers University

Reo Christenson, Miami University

Anne N. Costain, University of Colorado-

Boulder

James Davies, University of Oregon

Mario Falco, Loyola University 


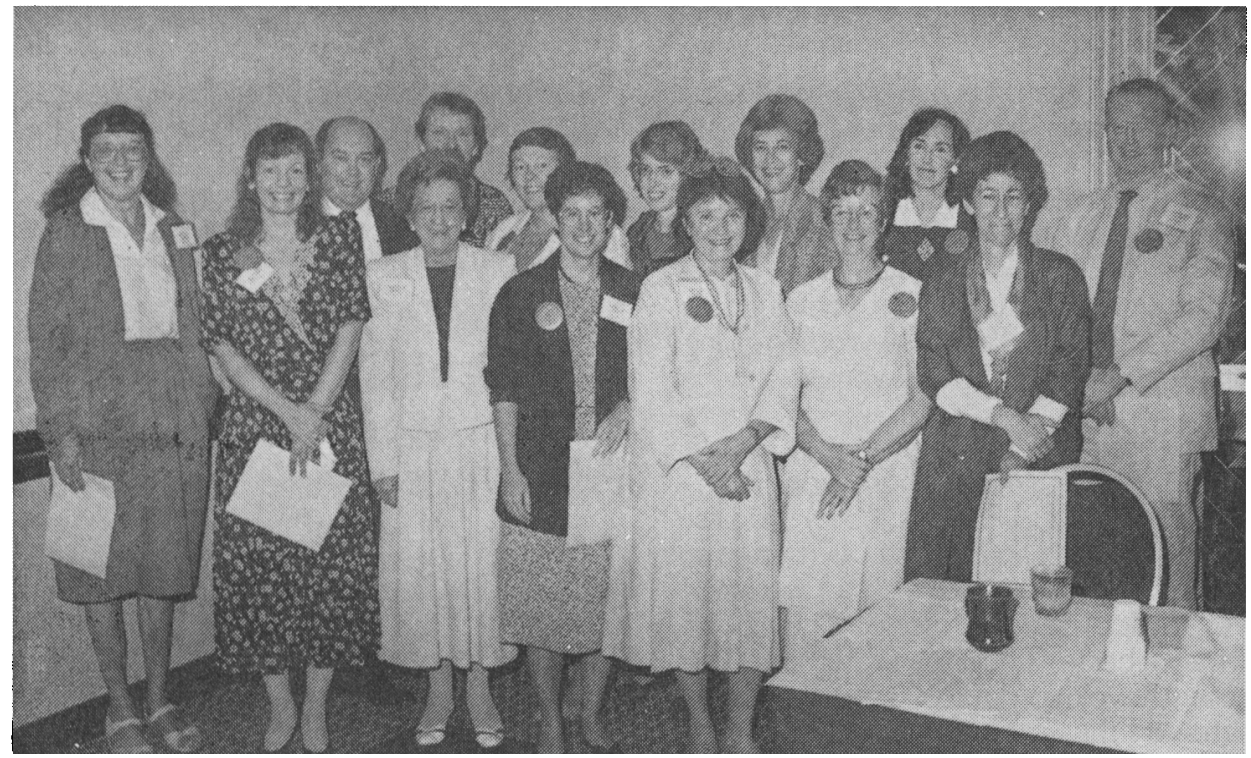

Mentors honored by Women's Caucus for Political Science. First row (l. to r.): Betty H. Zisk, Sue Tolleson-Rinehart, Roberta Sigel, Carolyn Ban, Betty Glad, Elinor Ostrom, Mary Fainsod Katzenstein. Second row (I. to r.): Philip Burgess, Jeff Fishel, Susan J. Carroll, Anne N. Costain, Dale Rogers Marshall, Susan O'Connor, and Donald Stokes.

Jeff Fishel, American University

Betty Glad, University of Illinois-Urbana

M. Kent Jennings, University of California, Santa Barbara

Mary Fainsod Katzenstein, Cornell University

Catherine Lovell, University of California, Riverside

Susan MacManus, University of South Florida

Dale Rogers Marshall, Wellesley College

John Brown Mason, California State University

Joyce Mitchell, University of Oregon

Betty Nesvold, San Diego State University

Karen O'Connor, Emory University

Elinor Ostrom, Indiana University

Mary Cornelia Porter, Barat College

Marie Provine, Syracuse University

Marie Rosenberg, Eastern Washington University

Roberta Sigel, Rutgers University

Donald Stokes, Princeton University

Sue Tolleson-Rinehart, Texas Tech University

Martha Whicker, Virginia Commonwealth University

Betty H. Zisk, Boston University

\section{Theodore J. Lowi Is APSA President-Elect}

Theodore 1. Lowi of Cornell University was elected president-elect of the APSA for 1989-90 and will assume the office of president in 1990-91. Lowi was elected by acclamation at the Annual APSA Business Meeting on September 2 in Atlanta, Georgia.

At the same meeting, Robert $\mathrm{H}$. Bates, Duke University; Nannerl Keohane, Wellesley College; and Michael Preston, University of Southern California, were elected vice-presidents for 1989-90. M. Crawford Young, University of Wisconsin, was elected Secretary for 1989-90; and David Brady of Stanford University. was elected Treasurer for 1989-91.

Eight new members of the 16-member Council were elected to serve a two-year term (1989-9I): Charles Bullock, University of Georgia; Gregory Caldeira, Ohio State University; James A. Caporaso, University of Washington; Kay Lawson, San 